\title{
A Glance at the Concept and Status of Employer Brand
}

\section{Siroos Zakipoor Kargany}

M.A. Human Resource Management,Faculty of Management, Tehran University, Tehran, Iran

\section{Leila Khosravi}

M.A. Industrial Management, Shiraz university, Shiraz, Iran

\begin{abstract}
Alireza Aboulhasani
M.A. Accounting, Faculty of Management and Accounting, Allameh Tabataba'i University, Tehran, Iran
\end{abstract}

Doi:10.5901/mjss.2016.v7n3s1p506

\begin{abstract}
Employer brand is one of the new management concepts that emphasizes on the importance and status of human sources, the employer brand follows the organizational status determination in active and potential staff's mind as the employer itself. This concept has been formed from all attempts and wide scientific researches in twentieth century about marketing, advertisement and branding and we can introduce it as the return to the importance and status of organizational human sources in the organizational internal source, the present article has attempted to expand the history, concept and requirements, applications and different aspects of employer brand by the use of theorists' new ideas. The literature of this theory is developed relatively and it provides the field for field and practical studies.
\end{abstract}

Keywords: Brand, Human Resource, Employer Brand, Marketing, Beneficial Competition

\section{Introduction}

The management science in recent years has done too many attempts for increasing the efficiency of organizations and increasing the human source efficiency. The human source is regarded as important section in organizational sources that from long time ago has been considered by operational managements and management theorists. The concentration and attempt by mangers and marketing theorists on criterions as marketing and branding and great volume of theories in this field has changed the brand and branding concept in twentieth century to familiar issue and of course all of concepts and various experiences. This issue of course has never reduced the value and importance of human source in organization and in the last period of twentieth century the employer brand concept was presented by management theorists to evaluate the importance and status of human source in organizations as the moving engine in organizations and the most illustrious value producing source in different institutions were considered to realize the organizational brand. Hence the employer brand concept could be emphasized and the management active individuals' return to importance and human source status in research are of the marketing and sale targets.

\subsection{Statement of Problem}

Human power in every organization has been under special attention as the most active and effective factor in product and service presentation from long time ago by many managers. In recent era many of scientists in management science and organizations have put their concentration on scientific efforts and experimental attempts to evaluate the efficiency strengthening methods and to effectuate the organizational human sources. The employer brand is the solution for effecting on human sources available in organizations and powers that might be employed in organization in future.

The organizational brand effectiveness on human power is assumed as the human source and it is the most important factor for human source companionship with targets and organizations needs and strategies and if this effectiveness leads to mangers and staff companionship, it will be effective in customers and organization relation strengthening and providing their requirements.

The present study is trying to increase the knowledge about the brand effect on potential human source and in 
expression this aspect of organizational brand effect is called employer brand. Therefore we try to increase the informational enhancement about the brand status in view and behavior and organizational staff performance and people who could be the organization future staff.

Based on reviewing about some related sources we can present below questions which are the key questions in research field.

1- What kind of conceptual criterions does the employer brand shape on people mind?

2- What is the forming mechanism of brand in organization at people mind from psychological view?

3- To what extent does the employer brand forming concept criterions is related to the field conditions as social, economical, industrial and environmental factors?

4- What kind of organizational mechanisms are influential in employer brand and what kind of special dynamic does exist about the time?

5- What kind of internal outcomes does the employer brand have for organization?

6- How can we provide required information about the employer brand?

\subsection{Significance of Study}

In new era, economical and commercial activities has wide complexities that heavy competition is one of them, to come up with the completion challenge, the organizational managers should continuously try to strengthen the organizational status in completion field, enforcing the organizational brand as the production main symbol in the customers mind, is the most important method for organizational status augmentation in completion field.

The brand concept at first was used for introducing products to potential and active customers because in classic ecumenical space, it was introduced as the main key for economical development and basically some named the classic economy science as the distributional side economy. In last periods of twentieth century, brand was assumed as the determinative tool for customers directing in different markets as it found such status that most people not only paid attention to brand status in consuming and buying behaviors, rather they had special view to other behaviors as employment in companies, signing servicing contract, selling primary materials. In other word, the brand which was formed for working power distributors gradually had effect on financial source, energy, primary martial distribution. The view that employed human source in organization and ready powers potentially could be volunteered to cooperate with organization is called the employer brand specifically about the organizational status.

Branding primarily was used for vivid products distinction, but during time it was used for human distinction, location and organization. Employer branding has been defined as the long run strategy for informational management that includes direct experiences and indirect relation with organization. It is necessary that organizations to invest on their branding as employer and they do branding for their products because staff are the organization internal customers. Today the employer brand is the effective tool for competition beneficiary. The employer branding is the realization process and organizational brand slogan making by the use of traditional marketing principal to achieve a superior employer condition is due to be selected as the best.

\subsection{Literature Review}

The brand term in addition to many of English language terms as (brandy, burn), in German language (like brennen) and many various examples in other languages is all related to the meaning of temperature, heat and spark. In old English language, the brand name in the Beowulf epic meant the destruction by fire. During the $19^{\text {th }}$ century in USA, ironing with high temperature on animals and burning different injuries was called brand and later on any kind of branding with iron was assumed the same. The brand concept began from 200 years ago. In the marketing field from $19^{\text {th }}$ century on, by emergence of products packing industry, brands also found new concept. According to some statements, the P press 1 soap was the first brand which registered commercially. In 1930 decades, the Procter Company was the first company that developed the brand management system. The first definition for brand advertisement in about 1900 was introduced by James Walter Timpson that today it has been changed to branding definition, early to great companies started to invent slogans that was heart in radio and the first TV advertisement was showed. In 1940 customers relations were increased socially, psychologically, humanistic and it led that many producers understand other brand values and necessity to apply them.

The employer brand is assumed as concepts that presented about 2 decades in marketing literature and human source management (Ambelonarou, 1996). Although different definitions as this concepts has been presented, maybe we can assume it as the image that formed from an organization specification in the employer role in the internal staff mind 
and working applicant in market about that organization.

"The concept of employer brand is strongly connected with human resource management and branding (Ansari and Riasi, 2016). Employees are among the most important resources of each organization (Riasi and Asadzadeh, 2015, 2016), therefore, it is necessary for managers to improve their brand image in their employees' minds in order to become more competitive in their business (Amiri Aghdaie et al., 2012; Riasi, 2015) and to increase their profits (Riasi and Amiri Aghdaie, 2012; Riasi and Pourmiri, 2015) "

\section{Brand}

\subsection{The brand concept}

The design, sign and symbol are the terms that has the same definition in dictionary that means earning, brands that distinct a model from other products to create an image is used and in time duration, this image in customers mind is jointed with level of validity, quality and satisfaction, therefore brands is jointed to customers in complicate market through benefit and value making. In brand definition there is general agreement, Ker points out to the brand identity, Chlor talked about the brand illustration and Berry considered the brand concept, according to all of these differences we can point out these similarities in literature. American marketing institution definition about the brand includes name, term, sign, design or combination of them which is used for realization of products and seller services or group of sellers and it make distinction in competitive environment compared to other rivals (Mohamadian and Ronaqhi, 2010).

According to inter brand company definition, brand is the combination of visual elements which are put near each other in a commercial name to make validity and superiority and more value for customers.

For a potential customer, brand is an important direction. Brands facilitate the dealing as the money. Customers' are faced with combination of harmless products or products which are difficult to be read and it is not possible to assess them perfunctorily. Brands and prices make the decision making easier in realization and removing confusion. Price of a product assesses the monitory value and commercial name identifies that product and reveal that product distinction.

\subsection{The brand reality is something exists in the customer mind}

According to what said, it is predicted that in the future accompanied with globalization of economy, it is not important any more where product or service is produced; rather the significant point is that what brand is carried by it. The brand could be assumed as invisible prosperity of an organization that leads to increase of a product or service final value for customer. This increase in final value finally leads to increase of added value and also increase of gained value by organization. In past most of organizations properties included in visible properties while today more than $80 \%$ of great companies' properties are hidden properties. In our country and in Farsi language the brand term is usually for product or service with high social value.

\subsection{Brand identity}

Akerin in 1996 defined the brand identity as the combination of human specifications related to the brand and declared that the brand identify assist the strategists to have complete realization about the people view to brand, and their brand is being separated from others and they proceed to take communicative actions and finally to make special value for their brand (wood, 2000). Because brands have their special identity, customers treat with brand as human which is proper and in the same direction with that identity and all previous steps from making confidence and relation with customer has been passed and achieved completion, in more simple explanation, the brand identity includes population specification as gender, age, social class that directly effects on the brand applicants and product marketer and also it effects on product specification indirectly.

For example, Marlboro is the name of cigarette brand that mostly used by men due to image which has been made of it, that is a powerful masculine cowboy, Mercedes bens cars frequently are seen in high class social level because the brand of Benz shows the high quality and efficiency, consumers usually choose brands which are similar to their imagination so the brand identity shows the personality of that person.

\subsection{The brand distinction}

The brand distinction is the vital factor that market people could make beneficiary competition in consuming products and 
also in service industries, the brand distinction actually shows the degree of company brand from other competitors and remain in the customer mind. The brand distinction is a strategic element that could be established by company for future development to be closer to its target fulfillment. One of the elements by which service institutions could make reliance is the deserved staff presence. Actually servicing to customer properly frequently is based on trained and motivated staff who behave with customers with respect

\subsection{Certainty about the brand}

Certainty shows the psychological condition and time is needed that one side finds confidence to other side, assurance about a brand is a psychological variable that reflects the hypothesis combination about the confidence and intention that a customer has about that bran, actually the assurance could be measured through the brand capability in providing promises given before (Vazifehdust, Kheiri and Rohany, 2010) have introduced brand as the customers' desire for reliance on brand capability to perform mentioned duty (Chaudhuri \& Holbrook, 2001).

\subsection{Loyalty to brand}

Making a powerful loyalty to buy or keeping a product or service lead to behavioral changes regardless of situational effects and marketing proceedings. American society of marketing defined loyalty or brands as below: the benefit according to which a customer buys from one distributor instead of buying it from some distributors frequently.

Sensual Loyalty shows the customer loyalty in all directions if practical loyalty is due to customer satisfaction and its symbol is the frequent purchases of that brand. So the difference between the brand loyalty and repeated purchasing behavior has signification, the repeated buying behavior means that customer frequently is buying product without special sense about it. In reverse loyalty to brand emphasize that customer has real superiority about the brand. The purchasing repeated behavior in people might be due to price discount and gifts which have given by seller, therefore only purchasing repetition does not representation of the brand complete loyalty.

Table 1. The relationship between customer behavior dimension and theory

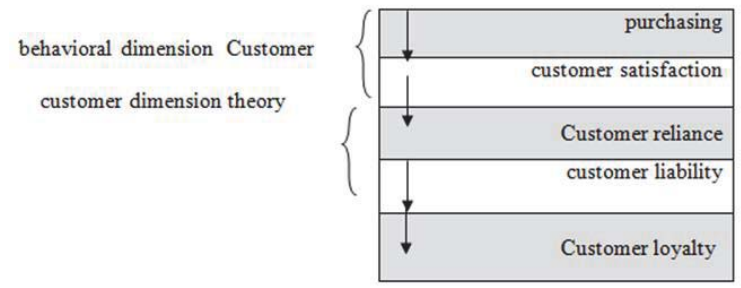

\subsection{Brand association}

The brand association includes everything that relates the customer mind to the brand, this association could be related to product, special geographical place, company, competition, venders, shops, symbols, design or special life style, the brand association in consuming products usually are in two groups, main associations and related to the product or irrelative associations as the brand identity, profile of applier, nationally or producer country, faces and social and cultural personalities are samples about the irrelative scales with product. In services also there are differences between the main services and facilitating services. These services main associations are related to the service presence reason, for example for a hotel the main point is the traveler inhabitance. Other services could be the reservation process or main services presentation; supporting associations are factors for making distinction and could make added value for main services. A restaurant, earning center or a mine water fountain are samples for supporting services that could assist hotels to distinct themselves from other competitors (O'CASS \& GRCE 2003).

\subsection{Employer brand concept}

Positive brand of an organization shows specifications that are made in that organization staff mind and enable applicants to determine it as proper environmental situation. Maybe one of the most important reasons is attention to this subject 
that achieving organizations to human sources has high efficiency in working market competition that necessarily it is not observed by an organization through staff employment strategies. This subject especially in service organization has been emphasized (Nacsferman, 2006). From other view the moral necessities to make proper environment for working and development of staff should have definite conceptual framework for value making in staff as group of beneficiaries. The employer brand is a course field. The client brand origin is in marketing and human source management. From the marketing view, organization is faced with markets and as the result triple marketing. The external marketing which is shaped by relation between the organization and customer is confirmed traditionally mainly by this marketing, the internal marketing whose formation is the relational function between the organization and staff and market between the reaction of staff and customers is formed relatively. The general performance of organization depends on how these three relations are shaped. Many of managers believe that external marketing do not have complexity and it does not achieve proper result. The market concept of internal customer argued that organizational staff are the first market for organization, as the result staff are the internal customer and internal product jobs should attract staff and develop them and motivate them to provide needs and requirements of this customers in the way of organization general targets. Katler defines the internal marketing as application, training and motivating capable staff in order to present proper services to customers.

Staff are in the center of organization branding and their behavior could lead to strengthen mentioned values or if any disconformities occur with values, advertised messages will be endangered; therefore it is really important that staff behaviors are in conformity with organization values (Bertonco et al, 2005). From the human source knowledge, having a talent tank, capabilities for an organization is really critical. The oxford dictionary defines talent as below; the capability for doing a job better and managing it better and to develop it as well. An organization makes relation with heart and minds of human and the most successful organizations, prospects and organizational values are parallel to people values and prospects, the employer brand is the view for values and prospects conformity and also keeping talents. The client brand expression was applied for the first time by Amblerobarou. They introduced the employer brand as the combination of efficient benefits and economical and psychological profit which is provided by employment and it is realized by employer organization. Since that time to now many definitions are presented about the employer brand and it is defined as the strategy by which the organization separates its internal capabilities by the purpose of assurance from deserved applicants and keeping its internal talents toward competitors. The sample of employer brand purpose includes increase of attraction for talents in future and making conformity for staff with organizational values and proliferation of role and importance of staff in missions and encouraging to self-recognition and satisfaction and belonging to the job and attention to equality in payment and working condition., the attraction key is protection and making belonging in staff and using innovativeness in everything that earning and working is belonged to it and reflects the employer brand, therefore people are protected and supported through suitable skills and when the staff relation is formed based on the confidence which lead to organizational dependence, finally the organization performs based on its strategies and fulfill its responsibilities about customers and all of this issues are formed in the organization. A brand only could be responsible when perform to its liability about organizational internal staff requirements and it should be made of internal believes. In this way the working and earning leaders will perform to their liabilities and staff also perform to their responsibility toward customers, hence earning and working will occupy a part of customers heart and finally leads to organizational success, the essence of this emotional relation is working and earning essence which is introduced to people publically (Sartain and Schumann, 2006).

If the brand does not build internally, a few numbers of people will believe it. Brand includes realization, sense and associations which exist inside the staff mind, employer brand existed from past unofficially either you try to form it or not. Kamordaniyosvas in 2010 in an article introduced the conceptual and theory basis of employer brand and its criterions as: working balance, life, culture and organizational environment, product brand power, organization, 3- benefits, 4- working environment. The operation of these criterions is presented in table 1 :

Table 2. Employer brand criterions

\begin{tabular}{|c|c|c|c|c|}
\hline Life- work balance & $\begin{array}{l}\text { Working environment } \\
\text { and culture }\end{array}$ & $\begin{array}{l}\text { Brand power/ organizational } \\
\text { product }\end{array}$ & Benefits & Working environment \\
\hline $\begin{array}{l}\text {-mission } \\
\text {-space } \\
\text {-time flexible } \\
\text {-keeping children } \\
\text {-working -hours } \\
\text {-holidays }\end{array}$ & $\begin{array}{l}\text {-supreme manager } \\
\text { quality } \\
\text {-fame } \\
\text {-technological level } \\
\text {-risk environment } \\
\text {-organizational - }\end{array}$ & $\begin{array}{l}\text {-fame(organizational service } \\
\text { or product requirement rate) }\end{array}$ & $\begin{array}{l}\text {-base salary } \\
\text {-outside equality (receiving } \\
\text { salary compared to other } \\
\text { companies) } \\
\text {-internal equality } \\
\text {-benefits }\end{array}$ & $\begin{array}{l}\text { management quality } \\
\text { coworkers condition } \\
\text {-realization } \\
\text {-rehabilitation } \\
\text {-working challenges } \\
\text {-international }\end{array}$ \\
\hline
\end{tabular}




\begin{tabular}{|l|l|l|l|l|}
\hline $\begin{array}{l}\text {-working facilities from } \\
\text { long distance }\end{array}$ & $\begin{array}{l}\text { order } \\
\text {-organizational size }\end{array}$ & $\begin{array}{l}\text {-stock options } \\
\text {-retired condition } \\
\text {-health and sanitary benefits }\end{array}$ & $\begin{array}{l}\text { motivation } \\
\text {-roles clarities } \\
\text {-project } \\
\text { responsibilities }\end{array}$ \\
\hline
\end{tabular}

Brand power: as identify human source Consultant Company has suggested, there are 5 steps for development of a powerful employer brand:

1- The organization realization

2- Invention of an obligatory liability for staff which reflects brand liabilities for customer.

3- Enhancing available standards for harsh conformity as all organization support and strengthen the brand liabilities.

4- Measuring the brand liabilities performance.

5- Performance and evaluation (Barton et al, 2005)

Baku Asutiku in 1996 in an article with conceptualization and research in branding of employer evaluated the relation between the organizational branding and job management and declared that branding the employer brand is the beneficial framework for human source management.

Martin et al in 2005 did not assume the employer branding due to three processes, the organizational branding importance and global branding, development in economical services is the center of all developed economies in the world and the increasing importance of invisible properties and mental wealth as the strategic benefits are put in to consideration. They assumed the brand management process as the core of decision making in organization.

Berton et al in 2005 declared that employer brand leads reduction of staff cost employment and it follows staff realization optimization, it assist the staff keeping and even organizations with more powerful employer brand could compete with organizations which have weaker employer brand. They recognized 25 factors which are effective on attraction in their studies.

Simaon and Chery in 2006 in an article with title of measuring and employer brand management evaluated the employer brand image in employers' idea and employed people at servicing organization and also they evaluated the continuous developing management application about the employer brand image in employment market. It should be mentioned that the made value in an organization is the outcome of staff activities in every level and each time. The solid relation in brand is the key issue for many of organizations and it provides more opportunity for development through beneficiaries linkage and brand followers. By solidification of what presented by organization to customers and staff and beneficiaries, these elements will assist each other.

Therefore it is necessary that they have similar expectation about the brand. The employer brand management does not replace new activity with older activity rather it gathers all together to make more effect. Also organizations could use employer brand for distinction between proper and improper staff, Guhlers Viluvich.

Concentration and operation of employer brand is a great investment for an organization, the process correct management and branding strategic effectiveness is also significant. Evaluation and measuring will show the organization that to what extent the brand has been influential.

According to Kaosutco theory in 2004, the employer brand will provide two main treasures as below:

1- employer brand correlation

2- employer brand loyalty

The most important issue is that in every condition, the employer brand will assist the organization to have deeper realization about the performance. The employer brand should support the earning and working strategy. The employer brand power is significant in making relation between internal experiences and external requirements, so in first step it is necessary that the earning and working strategy is identified, the employer brand should defined customer experiences for staff. If the employer brand is the only human source or communicational field, it never develops. The employer brand only progress when distinction is made for customers in results. The employer brand should realize all connection points and plan for all of them. A connecting point emerges when a customer make relation with service or generally with earning and working. The staff inside organization will affect the brand in every point on contact either having contact with customer or none.

Staff should realize the essence of earning and working and institutionalize it in themselves. Staff should believe it that how they should make a brand in the market exclusive. Every working and earning needs to have special treatment to his staff for performing the brand liabilities toward customers. Every organization should define the experience for its customers first, the staff roles in this case are different from one organization to another because every working is different from other, it is necessary that eh employer brand is concentrated on staff selection. 
A part of employer brand capacity is realization of staff about organization, the employer brand should be respondent to this question that why staff the main question is; what benefit exists for me?

The employer brand is powerful only if it has the capability to provide the earning and working requirements.

The employer brand should support the customer strategy, working and earning strategies which hare the main hear $t$ of achieving perfect job and brand assists staff to find meaning for the target and help them to realize their expectations and make the value sense in them and identify the working and earning as status for operation (Sartain and Schumann, 2006).

In table 2 the main definition about employer brand is summarized:

Table 3: A summery about the employer brand definition

\begin{tabular}{|l|l|}
\hline Embler and Bouver 1996 & $\begin{array}{l}\text { Combination of practical, economical, psychological benefits which are provided through employment } \\
\text { and they are realized by employer organization }\end{array}$ \\
\hline Lioud 2002 & $\begin{array}{l}\text { The combination of an organization attempts in making relation with present staff and future staff in } \\
\text { organization in order to make proper environment for workers }\end{array}$ \\
\hline Sartin Schumann 2007 & $\begin{array}{l}\text { How an organization shapes its identity based on the values and principals and what kind of liabilities it } \\
\text { accepts to provide customers' requirements. }\end{array}$ \\
\hline Vaker 2007 & $\begin{array}{l}\text { Combination of specification and features which are usually invisible and distinct the organization and } \\
\text { special type of employment experiences are guaranteed and asked the workers to perform the best } \\
\text { according to organizational culture and cause the organizational progress. The employer brand has been } \\
\text { used for achieving staff loyalty and relatively increasing the benefits and organizational success through } \\
\text { market distinction }\end{array}$ \\
\hline Minchingin 2007 & The employer brand is the long run strategy for attraction and making belonging and keeping talents \\
\hline
\end{tabular}

To response all questions completely in the problem presentation section, there are other key question but brief explanation are presented as the response to mentioned questions:

1- Conceptual criterions: it seems that the employer brand could be a various conceptual criterion combination. In sources which were reviewed maybe we can say that the mental image of people about phenomenon as employer systems (including service compensation system, performance management, job path and progress in future), cultural space and organizational leadership (including organizational culture and proper criterions as humanism and justice, innovation and leadership style like open and cooperative leadership) and spiritual status and social distinction ( organizational identify and its mission acceptance, actual effectiveness on social condition, cooperation in social responsibilities) are all the conceptual dimensions of employer brand.

2- The psychological formation mechanism: based on the research background that means the social psychology about making mental models from phenomenon it seems that forming the brand of employer is cognitive and affective and normative in various fields (Edvardez, 2009). Many different theories we can find which have developed by the use of theoretical framework about the employer brand psychological formation. This side of issue evaluation needs evaluations and theoretical contemplations but maybe we can say in summery that values, needs and mental models in people make a bed according to which special information from target organization are chosen, interpreted and used to prove the field for the employer brand formation, also the people correspondences in working market basis leads to informational exchange in the field of mental images at individual level and it emerges with employer brand different mechanism as the total concept.

3- Dependence to field factors: according to mentioned theories in pervious part, the national culture, industrial culture and expectation and mental models which have roots in social, economical realities and working market, are considered as the key factors informing the employer brand. The field factors motivates different expectations about the organization, for example in industrial and economical inflation factors as stability could provide great importance for employer brand while in growth period, factors as professional growth and relation with technology and knowledge might be more important aspect of employer brand, the result of these reactions either in identity or in outcome could be different for various target groups inside or outside of an organization.

4- The forming organizational mechanism: generally maybe we can say that the forming mechanism for employer brand might exist in all organizational criterions, first the management system outcomes for human source directly or indirectly is effective on this phenomenon through staff. For example the organizational reaction with applicants during interview, the mental status of staff when they leave the organization, realization about professional growth in different Medias directly could be evaluated; also the information transference which is 
related to organizational condition could be done through staff dialogues about payment of wages and working environment and culture and organizational leadership styles. This subject could be effective in service organizations in which staff directly have relation with others outside of organization, secondly economical scales of organization and its outcomes could be influential through social Medias in this field. The presented information to wealth markets and stock markets member companies' economical condition are also evaluable. According to the identity of employer brand concept and also its formation mechanism it seems that this phenomenon is formed during the time and its variation also is not possible probably, accurate studies is required for dynamic realization and changing of this phenomenon. The key point in this issue is: maybe by solid view we can attribute the employer brand in more public format of organizational brand and consider it as the organizational brand concept. Hence the employer brand is completely under the organizational brand and also a part of that (Fuster, Panjayer and Chang, 2010).

5- The employer brand outcomes: it could have results for organizational staff and for the whole system. The employer brand could strengthen staff identity and assumed as the liability and reliance factor. Maybe we can say that employer brand is the influential factor and also it is affected from culture and staff liabilities toward organization. The organization with positive employer brand also has the required basis for attracting applicants with high performance and capability. The effectiveness process is increased in such condition.

6- The method of achieving to employer brand information is using obtained information from job satisfaction evaluation and organizational dependency and valuable inputs about the internal aspects of this phenomenon; also the result of interviews in this case is considerable. About the employer brand inside an organization, performing measurement evaluation from target groups' and also holding central groups is assumed as methods to achieve valuable information about the employer brand, some of countries have gathered and compare information about different organizations employer brand. The sample has been considered before as (the best organization for working, reality or dream)

Above subjects were presented for development of employer brand and its importance because it seems that the status of this issue in our country either in university studies or in application of effective proceedings in addition to required discoveries in many primary steps, realization of strengthening method in this phenomenon is really essential at organizations which are based on human source with talent and high capability specially in condition that facing organizations attempt for changing earning and working space.

Reviewing the performed studies about employer brand and equipment and the levels of formation shows that most of theorists emphasize on edition and development of human source strategies development as the first step on branding to develop the employer brand parallel to human source strategy. Some believe that organizational brand is the first step in employer brand and deduct that employer brand tries to provide a location for staff that is understood through organizational brand. Some researchers assumed the employer brand as the combination of experiences and realization of staff and customers, hence they advise that to strengthen the brand, the staff motivating factors and needs should be realized through connecting channels. From mentioned ideas this result is obtained that realization and evaluation of present condition is the first step in branding of employer brand. The intended group for employer brand is the staff which hare available or potential in the organization. The employer brand has two sides, one side is the organization with specifications formed before and targets that must be fulfilled and from other hand there are staff that have an image from organization and they should be corrected or stabilized. In order to branding a successful employer, at first step it is necessary that both sides are realized, the proper inputs from organization to edit employer brand includes:

The organizational culture, organizational strategy, organizational brand and organizational product brand, from other hand, requirements and staff expectation should be realized and evaluated. In this step both the staff requirements and also working market upheavals are evaluated. In next step it is necessary that human source planning is done for staff expectation provision. Making flexibility to provide expectations are as factors which is confirmed by theorist, therefore the planning for providing motivating needs in staff should be done toward the mission and organizational prospects, the third step is performing the employer brand programs and it is necessary that some solutions are provided for assurance about the plans operation, the finally step is the assessment of performed proceedings effectiveness, advertisement and publication of distinction which have obtained from different channels to provide or increase of employer brand is considered as issues which are confirmed in branding process.

Steps and procedures for employer branding are presented in figure 1, attention to this point is necessary that a stable brand is made when expectations and requirements of all beneficiaries are considered, providing knowledge forces and lack of staff loyalty are the main challenges which are discussed in organizations. Researchers have shown that the employer brand should enter as strategic view in organizations management philosophy and it should have close relation with organization brand and its strategy, presenting proper services and customer satisfactory services is performed by 
human source to high extend, as it is confirmed correctly, respecting customers is done through respecting staff, application of employer brand view in industry is similar to car manufacturing factory that needs employment if expert forces and also needs many servicing processed after the car delivery, and it will have the considerable effect on customer satisfaction.

Table 4: Employer branding processes

\begin{tabular}{|l|l|}
\hline First step & $\begin{array}{l}\text {-evaluation ( in the first step the organizational culture, organizational strategy, organizational brand and also } \\
\text { needs and staff expectations are realized and evaluated }\end{array}$ \\
\hline Second step & $\begin{array}{l}\text {-making( in this step according to performed evaluation, many training and developing plans, employment and } \\
\text { protection, service compensation and retirements are edited) }\end{array}$ \\
\hline Third step & $\begin{array}{l}\text {-operation( in this step some strategies for operational plans are edited and they are designed and operated in } \\
\text { second step) }\end{array}$ \\
\hline Fourth step & -monitoring(it is evaluated in the effectiveness step for employment plans and protecting staff \\
\hline
\end{tabular}

In organizations it is necessary that more field evaluations are done in order to inspect the effective criterions on employer brand, according employer brand effect on organizational dependency and also conformity of staff with organizational values and their satisfaction will effect on customer satisfaction as well and also it will bring benefit for organization, this concept requires more field evaluation and its conceptualization is felt empty in internal scientific societies to high degree.

\section{Conclusion}

If different management theories are studied from the beginning, we realize that the human source importance has never been neglected, hence the employer brand concept could be assumed to confirm human source role in organizational targets fulfillment.

Two special points which are understood about the employer brand concept could be regarded as the great outcome of this concept in management knowledge.

1- Costs and attempts which are done by organization for formation and making organizational brand could encourage organizational human source to achieve the organizational targets. In other word as the powerful brands force customers to buy and make them loyal to buy their product, in the same way they can provoke their human forces for more services and wide attempts to fulfill organizational targets and potential human sources could be satisfied to choose the brand owner organization among rivals.

2- organziations should simultaneously and even before promoting their brand between customers, do their best to define themselves for potential and active staff as an employer with better and more valuable specification than other rivals. In other word the employer brand concept confirms on this point that formation of organizational brands in products and services market is started from a perfect employer in the potential and active staff mind and it will continued by keeping such mentality.

By such concept explanation, the employer brand is trying to make coordination and conformity and parallelism inhuman source with organizational targets and this conformity will make stable benefits for organization.

An organization staff with a famous employer brand name feels that they are working in an organization which has much more importance that other rivals and it realized the human source status better and tries to keep the employer benefits parallel to staff benefits and put its efforts for enhancement and strengthening its organization as much as possible. The potential human sources who could work in such organization prefer to be chosen by such employer and it leads to human sources stability inside the organization and from the other hand it provide opportunity for the organization to choose its required human forces among many job applicants in the market.

By reviewing issues mentioned in this research we understand that organization could make its human sources active, dynamic, diligent and loyal to the organization and its strategies and targets.

\section{References}

Alexandra,M.(2007).The Employer Brand: A Challenge for Human Resources Management, Review of Management and Economical Engineering, Vol. 6, No. 5.

Backhaus, K., \& Tikoo, S. (2004). Conceptualizing and researching employer branding. Career development international, 9(5), 501-517. Berthon, P., Ewing, M., \& Hah, L. L. (2005). Captivating company: dimensions of attractiveness in employer branding. International 
journal of advertising, 24(2), 151-172.

Buttenberg, K. (2013). THE IMPACT OF EMPLOYER BRANDING ON EMPLOYEE PERFORMANCE. New Challenges of Economic and Business Development-2013, 23.

Chaudhuri, A., \& Holbrook, M. B. (2001). The chain of effects from brand trust and brand affect to brand performance: the role of brand loyalty. Journal of marketing, 65(2), 81-93.

Danay Fard, Hasan, Seyed Mahdi Alvanie, Adel Azar, 2007, the quality research methodology in management, general view, Tehran, Safar publication

Davies, G. (2008). Employer branding and its influence on managers. European Journal of Marketing, 42(5/6), 667-681.

Dawn, S. K., \& Biswas, S. (2010). Employer branding: A new strategic dimension of Indian corporations.

Gehrels, S. A., De Looij, J., \& Frommer, H. M. A. (2011). Employer branding: A new approach for the hospitality industry. Research in Hospitality Management, 1(1), 43-52.

Knox, S., \& Freeman, C. (2006). Measuring and managing employer brand image in the service industry. Journal of Marketing Management, 22(7-8), 695-716.

Kolle, S. (2011). Alignment of Internally and Externally Aimed Employer Branding Efforts; A Case Study of the Novo Nordisk Employer Branding Programme 'life Changing Careers, Bachelor Thesis.

Kotler, P. (1994). Marketing management, analysis, planning, implementation, and control, Philip Kotler.

Martin, G., Beaumont, P., Doig, R., \& Pate, J. (2005). Branding: A New Performance Discourse for HR? European Management Journal, 23(1), 76-88.

Mohammdian, Mahmoud, Ronaghi,Mohammad Hossein, Strategies and techniques are improving: 50 practical way of branding, Publisher: Institute Mehraban book publishing 31 March, 2010.

Mosley, R. W. (2007). Customer experience, organizational culture and the employer brand. Journal of Brand Management, 15(2), 123134.

O'Cass A. and Grace D. (2003), "An exploratory perspective of service Brand Associations", The Journal of services Marketing, 17, 4/5, p. 455.

Sartain, L., \& Schumann, M. (2008). Brand from the inside: Eight essentials to emotionally connect your employees to your business. John Wiley \& Sons.

Vazifehdust, Kheiri,Bahram,and Rohany,Maryam 2011, "Risk aversion and brand loyalty", a brand season, No. IV, p 30-26

Winfield, J. (2005). The Branding Of Cities, Exploring City Branding and the Importance of Brand İmage. Master's thesis, Graduate School of Syracuse University, New York, USA.

Amiri Aghdaie, S. F., Seidi, M., and Riasi, A. (2012). Identifying the Barriers to Iran's Saffron Export by Using Porter's Diamond Model. International Journal of Marketing Studies, 4(5), 129-138

Ansari, A., \& Riasi, A. (2016). An Investigation of Factors Affecting Brand Advertising Success and Effectiveness. International Business Research, 9(4), 1-11

Riasi, A. (2015). Competitive Advantages of Shadow Banking Industry: An Analysis Using Porter Diamond Model. Business Management and Strategy, 6(2), 15-27

Riasi, A., and Amiri Aghdaie, S. F. (2013). Effects of a Hypothetical Iranian Accession to the World Trade Organization on Iran's Flower Industry. Consilience: The Journal of Sustainable Development, 10(1), 99-110

Riasi, A., \& Asadzadeh, N. (2015). The relationship between principals' reward power and their conflict management styles based on Thomas-Kilmann conflict mode instrument. Management Science Letters, 5(6), 611-618

Riasi, A., \& Asadzadeh, N. (2016). How Coercive and Legitimate Power Relate to Different Conflict Management Styles: A Case Study of Birjand High Schools. Journal of Studies in Education, 6(1), 147-159

Riasi, A., and Pourmiri, S. (2015). Effects of online marketing on Iranian ecotourism industry: Economic, sociological, and cultural aspects. Management Science Letters, 5(10), 915-926. 